\title{
ПОЛИЦЕЙСКОЕ ПРИНУЖДЕНИЕ
}

Кареева-Попелковская К.А.

\section{ПРАВОВОЕ РЕГУЛИРОВАНИЕ АКТОВ ПРИМЕНЕНИЯ МЕР ПРЕСЕЧЕНИЯ В ДЕЯТЕЛЬНОСТИ ПОЛИЦИИ}

A кты применения мер административного пресечения в деятельности сотрудников полиции занимают важное место в административной практике органов исполнительной власти. Вместе с тем акты применения мер административного пресечения являются разновидностью правоприменительных актов органов исполнительной власти 1 .

В административно-правовой литературе и, прежде всего в работах, посвященных правовым актам управления ${ }^{2}$, либо затрагивающих в той или иной мере проблемы форм управленческой деятельности ${ }^{3}$ и, в частности, правоприменительной деятельности органов управления ${ }^{4}$, также широко используются термины и понятия «индивидуальный акт управления», «правоприменительный акт управления», «ненормативный акт управления», причем вопрос о соотношении этих терминов и понятий, как правило, не затрагивается. Используются чаще первые два термина, неся при этом одинаковую смысловую нагрузку. Следует

\footnotetext{
${ }^{1}$ См.: Тюрин В.A. Проблемы применения мер в административном праве: дис. ... Д-ра юрид. наук. - М., 2004. - С. 199.

${ }^{2}$ См.: Копейчиков В.В. Правовые акты местных органов власти и управления: автореф. дис. ....канд. юрид. наук. - Харьков. 1952. - С.19.

${ }^{3}$ См.: Евтихиев И.И. Виды и формы административной деятельности органов государственного управления. M., 1948. - C. 83.

${ }^{4}$ См.: Коренев А.П. Нормы административного права и их применение. - М., 1978. - С. 87.
}

присоединиться к мнению большинства юристов, которые утверждают, что индивидуальные акты управления - это всегда акты применения права. В пользу такого утверждения свидетельствует следующее. Юридические свойства индивидуальных актов управления определяются, прежде всего, их связью с нормой права. Все индивидуальные акты управления издаются или совершаются на основе и в целях реализации правовых норм, причем таких, которые не могут быть реализованы без соответствующих государственно-властных предписаний. Поэтому индивидуальные акты управления выступают в качестве формы реализации правовых норм 5 .

Когда речь идет о реализации права государственными органами, подчеркивается, что она осуществляется в форме его применения, поскольку применять законы могут лишь уполномоченные на то государственные органы строго в рамках своей компетенции. Применение закона в ряде случаев связано с государственным принуждением, а это - область исключительно государственной деятельности. Отмеченные черты в полной мере присущи исполнительной и распорядительной деятельности - специфическому виду государственной деятельности. Она осущест-

\footnotetext{
${ }^{5}$ См.: Дворяк А.И. Меры административно-процессуального пресечения, применяемые милицией: автореф. дис. ... канд. юрид. наук. - М., 1996. - С. 16.
} 


\section{Полицейская деятельность 2 • 2014}

вляется в различных формах, к которым, согласно наиболее распространенной в административно-правовой литературе точке зрения, относятся правовые и не правовые ${ }^{6}$. Не правовые фрормы деятельности - материально-технические операции и организационная работа. При их осуществлении не издаются правовые акты управления. Применение права составляет существо исполнительно-распорядительной деятельности, является ее главным и определяющим выражением. Практически оно состоит в издании правоприменительных актов или административном распорядительстве ${ }^{7}$. При этом осуществление органами (должностными лицами) юридических актов правоприменительного характера выступает важнейшей фрормой административного распорядительства. С помощью правоприменительных актов прямые веления закона и других норм права применяются к конкретным обстоятельствам управленческой жизни в виде непосредственных юридически властных предписаний правоприменительного, т.е. точно определенного и персонифицированного характера и устанавливаются либо закрепляются, изменяются, прекращаются конкретные правоотношения ${ }^{8}$.

Обобщая изложенное, можно прийти к выводу, что важнейшие особенности и отличительные черты правоприменительных правовых актов управления обусловлены их связью с исполнительной и распорядительной деятельностью и выражаются в том, что названные акты:

- осуществляются на основе законов и других правовых актов органов государственной власти и управления, в целях их

\footnotetext{
${ }^{6}$ См.: Агеева Е.А. Формы управленческой деятельности исполкомов местных Советов. - М., 1973. - С. 104.

${ }^{7}$ См.: Аппарат управления социалистического государства. - М., 1976. Ч. 1. - С. 308.

${ }^{8}$ См.: Бочкарев И.Е. Административно-предупредительные меры, применяемые милицией (по материалам органов внутренних дел Нижегородской области): дис. ... канд. юрид. наук. - М., 2001. - С. 67.
}

реализации применительно к конкретным делам, возникающим в процессе функционирования органов управления, могут быть выражены в фрорме актов-документов или устных действий;

- относятся к исполнительной и распорядительной деятельности и к числу правовых средств ее организации и практического осуществления, чем обусловлено исключительно большое число и многообразие по содержанию и форме 9 .

Таким образом, очевидно, что правоприменительные правовые акты управления, взятые в совокупности, и каждый такой акт в отдельности, представляют собой конкретное правовое явление, отличаясь при этом сложным характером, вытекающим из особенностей проявления их сущности. Сущность же правоприменительных актов проявляется в их признаках как правовых актов управления, а также в чертах, которые характеризуют названные акты как разновидность правовых актов управления. Это позволяет говорить о принадлежности рассматриваемых актов, с одной стороны, к правовым актам управления средствам государственного управления, и, с другой стороны, к правоприменительным правовым актам. Такая двойная принадлежность затрудняет определение соответствующего понятия ${ }^{10}$.

Исходным для определения понятия правоприменительного правового акта управления следует избрать понятие правового акта управления с обязательным указанием видовых отличий данных актов ${ }^{11}$.

Правоприменительным актам, как и другим правовым актам управления, свойственны: подзаконность, государственно-властный, односторонний характер и юридические последствия. В необ-

\footnotetext{
${ }^{9}$ См.: Гапонов О.Н. Реализация мер обеспечения......: автореф. дис... канд. юрид. наук. М., 2006. - С. 11.

${ }^{10}$ См.: Дворяк А.И. Указ. раб. - С. 16.

11 См.: Пастушенко Е.Н. Функции административного принуждения по советскому законодательству: дис. ... канд. юрид. наук. - Саратов, 1986. - С. 10.
} 
ходимости соответствия всем требованиям закона, нормативных актов органов государственной власти, вышестоящих органов управления, а также правовым актам данного органа управления как по форме, так и по содержанию, а нередко и по порядку принятия, проявляется подзаконность актов управления ${ }^{12}$.

Властность актов обусловлена природой государственного управления как властно-организующей деятельности соответствующих органов. Властность в управлении наиболее отчетливо проявляется в характере отношений между субъектом и объектом управления, которые определяются как отношения власти-подчинения. Однако, будучи обусловлена особенностями состояния взаимоотношений субъектов и объектов управления, властность актов не связана с непосредственной подчиненностью ${ }^{13}$. Поэтому акты могут осуществляться соответствующими субъектами управления как в отношении подчиненных, так и неподчиненных непосредственно объектов. Управленческие отношения - субординационные, властно-организационные, распорядительные. Когда исполнительная деятельность находит свое проявление в правовом акте, она всегда выражение власти ${ }^{14}$.

Субъект управления выступает от имени государства и в его интересах, поэтому действует властно. Властный характер актов управления находит свое проявление в односторонности и обязательности. Только одна сторона в управлении может принять юридически властное официальное решение. Следовательно, правоприменительные акты управления, как и все правовые акты управления, - это акты од-

\footnotetext{
${ }^{12}$ См.: Тюрин B.A. Проблемы применения мер в административном праве: дис. ... Д-ра юрид. наук. - М., 2004. - С. 191.

13 См.: Козлов Ю.М. Административные правоотношения. - М., 1967. - С. 92.

${ }^{14}$ См.: Опарин В.Н. Правовое регулирование применения мер.....: автореф. дис... канд. юрид. наук. - Омск, 1998: автореф. дис. ... канд. юрид. наук. - Омск, 1998. - С. 9.
}

носторонние. Принятию таких актов может предшествовать согласование, либо они могут быть приняты по инициативе другой стороны, например, гражданина (разрешение на охоту, распоряжение о приеме на работу и т. д.). Но, издавая (совершая) правоприменительный акт управления, орган управления всегда действует в одностороннем порядке.

Властностью и односторонностью характеризуется сущность конкретных методов управляющего воздействия, находящих свое закрепление и выражение в акте управления. Это - административные методы. Такие методы еще не есть принуждение. Это - всего лишь юридически властные способы решения определенных вопросов ${ }^{15}$.

Властный характер находится в тесной связи с обязательностью актов управления, предопределяет ее, является ее важной предпосылкой и гарантией. Специфика обязательности правоприменительных актов управления в том, что в отличие от норм права, обязательных, как правило, для лиц абстрактных, правоприменительные акты обязательны для лиц конкретных. Они должны быть восприняты как обязательные теми, кому адресованы. Адресаты не вправе оценивать обязательность акта, отказаться от его выполнения, или выполнить такой акт только частично. Здесь же следует отметить обязательность акта для органа, его осуществившего. Органы государственного управления могут отменять или изменять свои акты, но до тех пор, пока акт не изменен или не отменен в установленном порядке, он имеет обязательное для этого органа значение ${ }^{16}$.

Наконец, надо подчеркнуть, что обязательность, как проявление властности,

\footnotetext{
15 См.: Тюрин В.А. Проблемы применения мер........ дис. ... д-ра юрид. наук. - М., 2004. - С. 192.

${ }^{16}$ См.: Опарин В.Н. Правовое регулирование применения мер...... автореф. дис. ... канд. юрид. наук. - Омск, 1998. - C. 9 .
} 


\section{Полицейская деятельность 2 • 2014}

обеспечивается возможностью применения принудительного исполнения актов либо санкциями за их неисполнение или ненадлежащее исполнение.

Правоприменительные акты управления проявляют себя как особая разновидность управленческих решений, имея наряду с другими правовыми актами управления в общей массе управленческих решений наибольший удельный вес. При этом они выступают как одно из важных средств правового воздействия, общим объектом которого являются, как известно, поведение, действия, поступки людей. Правовая форма воздействия на поведение людей вполне обоснованно рассматривается в научной литературе как специфическая фрорма управленческого воздействия ${ }^{17}$. Причем посредством правоприменительных актов осуществляется индивидуальное управленческое воздействие права на общественные отношения - в отличие от нормативного воздействия, осуществляемого нормативными актами. Таким образом, правовое воздействие находит свое проявление, прежде всего в правовых актах управления. Именно в них обнаруживается «юридическая связь субъекта и объекта управления, в рамках которой обеспечивается должное поведение последнего» ${ }^{18}$. Как и другие правовые акты управления, акты правоприменительные выступают не только средством, но и проводником этого воздействия и являются юридическими актами, с помощью которых направляется поведение и деятельность людей и их коллективов. Правоприменительный акт управления выступает одновременно как волевое властное действие по управлению - управленческое решение и волеизъявление, как носитель и выразитель управленческого воздействия и

\footnotetext{
17 См.: Акты управления (вопросы теории): межвузовский сб. науч. тр. - Иваново, 1987.

${ }^{18}$ См.: Козлов Ю.М. Правовые акты и методы управления экономикой / Управление и право. - М., 1985. - С. 32.
}

правового воздействия; в нем выражаются конкретные методы такого воздействия ${ }^{19}$.

Вместе с тем главным и определяющим свойством исследуемых актов является их правоприменительный характер. Правоприменительные акты не являются источниками права, поскольку не устанавливают новых норм и не отменяют и не изменяют существующих. Если правоприменительный акт направлен на одно, конкретное отношение, то нормативным актом регулируется вид типичных отношений. Действие нормативного акта не исчерпывается реализацией содержащихся в нем предписаний. К тому же, как правило, нормативный акт не имеет конкретного адресата. Правоприменительные акты управления не имеют чаще всего четкой внутренней структуры, по способу внешнего выражения, как отмечалось, могут быть как письменными, так и устными. Нормативные акты управления выступают в качестве правовой основы осуществления правоприменительных актов ${ }^{20}$.

В процессе осуществления государственной управленческой деятельности органы управления не только издают правоприменительные правовые акты либо устанавливают, изменяют нормы права, которые воплощаются в нормативных актах, но и дают директивы в предписаниях общего характера. Юридическая природа таких предписаний не может быть охарактеризована однозначно, поскольку они могут отличаться как признаками нормативности, так и признаками правоприменительного характера.

Рассмотрение сущности и особенностей правоприменительных актов управления позволяет определить каждый такой акт как одностороннее волевое властное действие, совершаемое органом государ-

\footnotetext{
19 См.: Рябов Ю.С. Административно-предупредительные меры по советскому праву: автореф. дис. ... канд. юрид. наук. - М., 1973.

${ }^{20}$ См.: Дворяк А.И. Указ. раб. - С. 16.
} 
ственного управления в соответствии с законом по реализации норм права в связи с конкретным делом, возникающим в процессе функционирования этого органа, вызывающее возникновение, изменение или прекращение конкретных правоотношении и выражаемое в фрорме актов-документов или устных распоряжений.

Важнейшими актами применения мер административного пресечения являются: протокол об администраивном правонарушении, в который заносятся сведения о применениии мер адмистративного пресечения и рапорт о применении некоторых мер адмнистративного пресечения (например, рапорт о применении сотрудников полиции огнестрельного оружия). Итак, протокол (постановление) об административном правонарушении является процессуальным документом, служащим основанием для возбуждения производства по делу об административном правонарушении, поскольку в данном документе фриксируется фракт совершения соответствующего нарушения ${ }^{21}$.

Полномочия должностных лиц прямо предусматриваются в законодательных актах, устанавливающих административную ответственность. Нередко полномочия должностных лиц по составлению протоколов об административных правонарушениях федеральным законодательством не предусматриваются. Об их наличии свидетельствует то, что на определенные органы (должностных лиц) возложены контрольно-надзорные функции. Осуществление указанных функций неразрывно связано с выявлением и фиксацией фрактов нарушения соответствующих предписаний.

Контрольно-надзорные полномочия могут быть нормативно закреплены и в специальных положениях, регулирующих правовой статус некоторых органов. Перечень категорий должностных лиц,

\footnotetext{
${ }^{21}$ См.: Тюрин В.А. Проблемы применения мер........ дис. ... д-ра
} юрид. наук. - М., 2004. - С. 194. уполномоченных составлять протоколы об административных правонарушениях, можно определить, исходя из содержания гл. 22-23 КоАП РФ (и соответствующих статей других законодательных актов). В этих статьях перечислены лица, уполномоченные рассматривать дела об административных правонарушениях, и налагать административные взыскания. Очевидно, что они вправе и составлять протоколы о соответствующих правонарушениях. Составлением указанных протоколов занимаются те должностные лица, которые непосредственно осуществляют контрольно-надзорную деятельность. В качестве примера можно привести контролеров-ревизоров и билетных контролеров пассажирского городского и междугородного автомобильного транспорта и электротранспорта, районных государственных инспекторов органов рыбоохраны и других лице22.

В некоторых случаях установления ответственности за те или иные административные правонарушения сложно определить лиц, уполномоченных составлять протоколы об административных правонарушениях. Это касается, например, непредоставления на безвозмездной основе услуг по погребению, а равно невыплаты социального пособия на погребение или невыполнения решений, принятых на местном референдуме, на собраниях (сходах) граждан, решений органов местного самоуправления и должностных лиц местного самоуправления ${ }^{23}$.

Следует иметь в виду, что надзор за исполнением законов, действующих на территории Российской Федерации, осуществляется прокуратурой. В соответствии со ст. 25 Федерального закона от 17 ноября 1995 г. «О прокуратуре Российской Федерации» ${ }^{24}$ прокурор уполномочен возбуждать дело о любом ад-

\footnotetext{
${ }^{22}$ См.: Пастугенко Е.Н. Функции административного принуждения .......... дис. .....- С. 20.

${ }^{23}$ См.: Дворяк А.И. Указ. раб. - С. 16.

${ }^{24}$ См.: Собр. зак-ва РФ. - 1995. - № 47. - Ст. 4472.
} 


\section{Полицейская деятельность 2 • 2014}

министративном правонарушении; при этом выносится мотивированное постановление.

Наделение полномочиями по составлению протоколов об административных правонарушениях представителей общественных организаций или органов общественной самодеятельности должно осуществляться исключительно в законодательном порядке. Случаи, когда протокол (постановление) не составляется, предусмотрены в ст. 28.6 КоАП РФ об административных правонарушениях.

Протокол (постановление) об административном правонарушении является основным процессуальным документом, на основании которого принимается решение по делу об административном правонарушении. Именно в этом документе фриксируются основные сведения, отражающие сущность совершенного нарушения и характеризующие личность нарушителя. Поэтому в законодательном порядке закрепляется содержание протокола (постановления) об административном правонарушении 25 .

В протоколе (постановлении) об административном правонарушении указывается: когда, где и кем он составлен. Важное значение имеет указание должности лица, составившего протокол (постановление) об административном правонарушении. В случае составления протокола (постановления) неправомочным лицом он признается ничтожным и должен быть возвращен в орган, где был составлен. В протокол (постановление) заносятся сведения о личности нарушителя. Помимо фрамилии, имени и отчества лица, совершившего правонарушение, необходимо фриксировать дату его рождения, поскольку административная ответственность наступает с 16-летнего возраста, а к лицам в возрасте от 16 до 18 лет применяются меры, предусмотренные Положением о комиссиях по делам несовершеннолетних. Указываются

${ }^{25}$ См.: Пастушенко Е.Н. Там же. - С. 20. сведения о гражданстве, месте работы и должности нарушителя, поскольку Кодексом Российской Федерации об административных правонарушениях предусмотрены определенные особенности решения вопросов о привлечении к административной ответственности должностных лиц, военнослужащих и иных лиц, на которых распространяется действие дисциплинарных уставов, а также иностранных граждан ${ }^{26}$.

В протоколе (постановлении) об административном правонарушении должны содержаться сведения о месте жительства нарушителя, его семейном положении, количестве лиц, находящихся на его иждивении, а также размере его заработной платы или иного заработка, пенсии или стипендии.

Необходимость фриксации указанных сведений обусловлена тем, что при наложении взыскания учитываются личность и имущественное положение нарушителя, а также смягчающие обстоятельства, к которым относятся совершение нарушения при стечении тяжелых личных или семейных обстоятельств, совершение правонарушения несовершеннолетним, беременной женщиной или женщиной, имеющей ребенка в возрасте до 1 года.

Кроме того, следует иметь в виду, что привлечению к административной ответственности подлежит, естественно, лишь вменяемое лицо.

Сведения о личности нарушителя устанавливаются по имеющимся у него документам. В случае отсутствия документов, удостоверяющих личность, необходимые сведения могут быть проверены в адресном бюро, а также по месту жительства и работы нарушителя с помощью телефонной связи. В целях установления личности нарушителя допускаются административное задержание лица, личный досмотр,

${ }^{26}$ См.: Мосин М.В. Правовые основания, процессуальный порядок и тактика административного задержания: автореф. дис. ... канд. юрид. наук. - М., 2006. - С. 17. 
досмотр вещей, транспортных средств и изъятие вещей и документов ${ }^{27}$.

Федеральным законом от 7 февраля 2011 г. «О полиции» ${ }^{28}$ определено, что полиция защищает право каждого на свободу и личную неприкосновенность. До судебного решения в случаях, установленных настоящим Федеральным законом и другими федеральными законами, лицо не может быть подвергнуто задержанию на срок более 48 часов.

Полиция имеет право задерживать:

- лиц, подозреваемых в совершении преступления, а также лиц, в отношении которых избрана мера пресечения в виде заключения под стражу, - по основаниям, в порядке и на срок, которые предусмотрены уголовно-процессуальным законодательством Российской Федерации;

- лиц, совершивших побег из-под стражи, лиц, уклоняющихся от отбывания уголовного наказания, от получения предписания о направлении к месту отбывания наказания либо не прибывших к месту отбывания наказания в установленный в указанном предписании срок, - до передачи их соответствующим органам, учреждениям или должностным лицам этих органов и учреждений;

- лиц, уклоняющихся от исполнения административного наказания в виде административного ареста, - до передачи их в места отбывания административного ареста;

- лиц, находящихся в розыске, - до передачи их соответствующим органам, учреждениям или должностным лицам этих органов и учреждений;

- лиц, в отношении которых ведется производство по делам об административных правонарушениях, - по основаниям, в порядке и на срок, которые предусмотрены законодательством об административных правонарушениях;

- военнослужащих и граждан Российской Федерации, призванных на военные

\footnotetext{
${ }^{27}$ См.: Мягков А.В. Указ. раб. - С. 41.

${ }^{28}$ См.: Собр. зак-ва РФ. - 2011. - № 7. - Ст. 900.
}

сборы, подозреваемых в совершении преступления, - до передачи их военным патрулям, военному коменданту, командирам воинских частей или военным комиссарам;

- лиц, уклоняющихся от исполнения назначенных им судом принудительных мер медицинского характера или принудительных мер воспитательного воздействия, до передачи их в учреждения, обеспечивающие исполнение таких мер;

- лиц, уклоняющихся от следования в специализированные лечебные учреждения для исполнения назначенных им судом принудительных мер медицинского характера, - по основаниям, в порядке и на срок, которые предусмотрены фредеральным законом;

- лиц, допустивших нарушение правил комендантского часа, - по основаниям, в порядке и на срок, которые предусмотрены федеральным конституционным законом;

- лиц, незаконно проникших либо пытавшихся проникнуть на охраняемые объекты, - до выяснения личности, но на срок не более трех часов;

- лиц, предпринявших попытку самоубийства либо имеющих признаки выраженного психического расстройства и создающих своими действиями опасность для себя и окружающих, - до передачи их в лечебные учреждения либо по месту жительства;

- лиц, совершивших побег из психиатрического лечебного учреждения или скрывающихся от назначенной судом недобровольной госпитализации в такое учреждение, - до передачи их в психиатрическое лечебное учреждение;

- лиц, в отношении которых поступило требование о выдаче, - до передачи их иностранному государству по основаниям, в порядке и на срок, которые предусмотрены законодательством Российской Федерации или международным договором Российской Федерации.

В каждом случае задержания сотрудник полиции обязан разъяснить лицу, под- 
вергнутому задержанию, его право на юридическую помощь, право на услуги переводчика, право на уведомление близких родственников или близких лиц о фракте его задержания, право на отказ от дачи объяснения ${ }^{29}$.

Задержанные лица, находящиеся при них вещи и документы, а также их транспортные средства подвергаются досмотру в порядке, установленном законодательством об административных правонарушениях, если иной порядок не установлен федеральным законом. Задержанное лицо в кратчайший срок, но не позднее трех часов с момента задержания, если иное не установлено уголовно-процессуальным законодательством Российской Федерации, имеет право на один телефонный разговор в целях уведомления близких родственников или близких лиц о своем задержании и месте нахождения. Такое уведомление по просьбе задержанного лица может сделать сотрудник полиции ${ }^{30}$.

О каждом случае задержания несовершеннолетнего полиция незамедлительно уведомляет его родителей или иных законных представителей. О задержании военнослужащего полиция уведомляет командование воинской части, в которой он проходит военную службу. О задержании иностранного гражданина или подданного иностранного государства полиция уведомляет посольство (консульство) соответствующего государства.

В полиции в порядке, определяемом федеральным органом исполнительной власти в сорере внутренних дел, ведется реестр лиц, подвергнутых задержанию. Сведения, содержащиеся в реестре, не могут быть переданы третьим лицам, за исключением случаев, предусмотренных федеральным законом. О задержании составляется протокол, в котором указы-

\footnotetext{
${ }^{29}$ См.: Пастушенко Е.Н. Функции административного принуждения ......: дис. ...-С. 10.

${ }^{30}$ См.: Мягков А.В. Указ. раб. - С. 52.
}

ваются дата, время и место его составления, должность, фрамилия и инициалы сотрудника полиции, составившего протокол, сведения о задержанном лице, дата, время, место, основания и мотивы задержания, а также фракт уведомления близких родственников или близких лиц задержанного лица.

Протокол о задержании подписывается составившим его сотрудником полиции и задержанным лицом. В случае если задержанное лицо отказывается подписать протокол, в протоколе о задержании делается соответствующая запись. Копия протокола вручается задержанному лицу (ст. 14).

Особое значение имеют сведения о том, привлекался ли ранее нарушитель к административной ответственности, поскольку в ряде статей Особенной части КоАП Российской Федерации предусмотрена повышенная ответственность за повторное совершение соответствующих правонарушений.

Помимо этого, согласно общему правилу, повторное в течение года совершение однородного правонарушения лицом, ранее подвергавшимся административному взысканию (а также лицом, ранее совершившим преступление), признается обстоятельством, отягчающим ответственность. При этом требуется учитывать срок, по истечении которого лицо считается не подвергавшимся административному взысканию. Данные о лицах, которые были привлечены к административной ответственности, устанавливаются с помощью учетов, ведущихся в органах, применяющих соответствующие меры административного взыскания.

В протоколе (постановлении) об административном правонарушении фиксируются место и время совершения нарушения, указывается существо правонарушения.

Фиксация места совершения правонарушения необходима, поскольку, по общему правилу, дело об административном правонарушении рассматривается по ме- 
сту его совершения. Указание на время совершения правонарушения имеет важное значение в силу того, что, по общему правилу, административное взыскание может быть наложено не позднее 2 месяцев со дня совершения правонарушения ${ }^{31}$.

Подробное описание существа совершенного правонарушения необходимо для его правильной квалификации, т.е. определения того, какой статьей Особенной части КоАП РФ или каким иным нормативным актом предусмотрена административная ответственность за подобные действия (бездействие). Кроме того, следует учитывать, что КоАП РФ предусмотрено освобождение от административной ответственности за действия, совершенные в состоянии крайней необходимости или необходимой обороны, а также в случае малозначительности совершенного правонарушения ${ }^{32}$.

Следует иметь в виду и то, что определенные обстоятельства совершения правонарушения (в частности, продолжение противоправного поведения, несмотря на требование уполномоченных на то лиц прекратить его; совершение нарушения группой лиц и др.) относятся к обстоятельствам, отягчающим административную ответственность.

В протоколе (постановлении) об административном правонарушении указывается статья Особенной части настоящего Кодекса или иной нормативный акт, которым установлена ответственность за совершенное нарушение. Необходимость этого обусловлена тем обстоятельством, что рассмотрение дел об административных правонарушениях осуществляется в соответствии с подведомственностью указанных дел. Так, в главах 22-23 КоАП РФ установлено, какие категории дел об административных правонарушениях уполно-

\footnotetext{
${ }^{31}$ См.: Пастушенко Е.Н. Функции административного принуждения........ дис. ....- С. 20.

${ }^{32}$ См.: Мосин М.В. Указ. раб. - С. 13
}

мочены рассматривать те или иные органы (должностные лица).

В протоколе (постановлении) об административном правонарушении указываются фамилии и адреса свидетелей и потерпевших, в том случае, если таковые имеются. Важно обратить внимание на то, что наличие свидетелей не является обязательным условием при составлении протокола, как иногда полагают отдельные лица, осуществляющие рассмотрение дел об административных правонарушениях. Очевидно, однако, что свидетельские показания, как и показания потерпевшего, способствуют установлению фрактических обстоятельств совершения нарушения, являясь источниками доказательств по делу.

В протоколе (постановлении) об административном правонарушении фриксируются объяснения нарушителя. Наличие данных объяснений также служит одним из источников доказательств по делу. Именно исходя из объяснений нарушителя, можно сделать вывод о наличии его вины в содеянном и выявить обстоятельства, смягчающие ответственность, например, чистосердечное раскаяние или способствовавшее совершению нарушения сильное душевное волнение ${ }^{33}$.

В протоколе (постановлении) об административном правонарушении фриксируются и иные сведения, необходимые для разрешения дела. Это касается, например, описания нанесенного ущерба, что характерно для отдельных правонарушений. Кроме того, следует иметь в виду, что в протоколе об административном правонарушении может быть сделана запись о проведенном личном досмотре и досмотре вещей, изъятии вещей и документов ${ }^{34}$.

Офрормление протокола (постановления) завершается его подписанием лицом, которое его составило, и лицом, которое совершило административное правонару-

\footnotetext{
${ }^{33}$ См.: Мосин М.В. Указ. раб. - С. 17.

${ }^{34}$ См.: Мягков А.В. Указ. раб. - С. 57.
} 
шение. В случае наличия свидетелей и потерпевших желательно чтобы протокол был подписан также и этими лицами, удостоверяющими тем самым правильность изложения в нем соответствующих сведений.

Подпись лица, совершившего правонарушение, не может рассматриваться как его безусловное согласие с содержанием протокола (постановления). Данное лицо имеет право представить свои письменные объяснения и замечания по содержанию протокола (постановления), которые прилагаются к указанному процессуальному документу.

Лицо, совершившее правонарушение, имеет право отказаться от подписания протокола (постановления). В таком случае в указанном процессуальном документе делается специальная запись об этом. Данное лицо вправе изложить свои мотивы отказа от подписания протокола, что также должно быть зафиксировано и приобщено к материалам дела.

Важно обратить внимание на то, что при составлении протокола нарушителю разъясняются его процессуальные права и обязанности, причем об этом делается специальная отметка в протоколе ${ }^{35}$.

В случае неправильного составления протокола его следует возвратить в тот орган, где он был составлен, для устранения соответствующих недостатков. После того как протокол (постановление) об административном правонарушении составлен, офрормлены другие материалы дела, они направляются органу (должностному лицу), который уполномочен рассматривать данное дело. При направлении протокола (постановления) об административном правонарушении необходимо правильно определить подведомственность дела. Для этого следует определить, какой орган (должностное

\footnotetext{
35 См.: Попугаев Ю.И. Административно-процессуальные меры, применяемые в связи с совершением правонарушения: автореф. дис. ... канд. юрид. наук. - М., 1991. - C. 8 .
}

лицо) уполномочен рассматривать дело о таком правонарушении ${ }^{36}$.

Затем требуется установить место рассмотрения дела. По общему правилу дело об административном правонарушении рассматривается по месту его совершения, однако административные комиссии и комиссии по делам несовершеннолетних рассматривают дела по месту жительства нарушителя. Имеются и некоторые другие особенности определения места рассмотрения этому органу (должностному лицу) некоторых категорий дел.

В том случае, когда дело рассматривается руководителем того органа, должностное лицо которого составило протокол об административном правонарушении, материалы дела передаются указанным должностным лицом.

Если же дело должно быть рассмотрено иным органом (должностным лицом иного органа), то материалы дела направляются на рассмотрение этому органу (должностному лицу) руководителем того органа, где был составлен протокол. Постановление прокурора (его заместителя) о возбуждении дела об административном правонарушении направляется им на рассмотрение уполномоченному органу (должностному лицу).

В случае возвращения протокола и других материалов дела об административном правонарушении в связи с тем, что они неправильно составлены, указанные материалы после устранения недостатков повторно направляются на рассмотрение тому же органу (должностному лицу).

Сроки составления и направления на рассмотрение протокола (постановления) об административном правонарушении не установлены. Однако следует учитывать сроки наложения административного взыскания, по истечении которых применение мер административного взыскания не допускается. Копия протокола об административном пра-

\footnotetext{
${ }^{36}$ См.: Дворяк А.И. Указ. раб. - С. 16.
} 
вонарушении в обязательном порядке вручается лицу, совершившему данное нарушение (т.е. привлекаемому к ответственности). Что касается потерпевшего, то вручение ему копии соответствующего протокола производится лишь в случае его просьбы (независимо от того, в какой форме - устной или письменной - она высказана) ${ }^{37}$.

Поскольку производство по делу об административном правонарушении отличается оперативностью, предусматривается, что вручение копии протокола об административном правонарушении осуществляется немедленно (т.е. в максимально короткий срок) после составления протокола. Протокол об административном правонарушении относится к числу важнейших процессуальных документов, ознакомление с которыми представляет собой одно из существенных прав участников производства по делу. Поэтому специально установлено, что копия такого протокола вручается соответствующему лицу только под расписку (которая составляется в произвольной фрорме) ${ }^{38}$. Предписания о вручении копий протокола - процессуального документа, служащего основанием для возбуждения дела об административном правонарушении, не распространяются на постановления о возбуждении соответствующих дел, выносимые прокурорами и их заместителями.

В специально установленных законодательством случаях предусмотрено осуществление производства по делу об административном правонарушении в особом, упрощенном порядке - без составления протокола об административном правонарушении ${ }^{39}$.

Для некоторых мер административного пресечения административным законодательством установлено составле-

\footnotetext{
${ }^{37}$ См.: Дворяк А.И. Указ. раб. - С. 16.

${ }^{38}$ См.: Попугаев Ю.И. Указ.раб. - С. 8.

39 Куракин А.В. Компетенция полиции в сфере реализации законодательства об административных правонарушениях // Административное и муниципальное право. 2013. - № 6. - C. 123 .
}

ние отдельного протокола. В частности, это административное задержание. Согласно ст. 27.4 КоАП РФ об административном задержании составляется протокол, в котором указываются дата и место его составления, должность, фрамилия и инициалы лица, составившего протокол, сведения о лице, подвергнутом административному задержанию, время, место и мотивы задержания.

Протокол об административном задержании подписывается должностным лицом, его составившим, и лицом, подвергнутым административному задержанию. В случае отказа лица, подвергнутого административному задержанию, от подписания протокола, в нем производится соответствующая запись. Об административном задержании составляется протокол. В нем указываются: дата (год, месяц, день) и место составления протокола (орган внутренних дел, орган местного самоуправления); должность, фамилия, имя и отчество лица, составившего протокол; кто задержан (основные данные о личности задержанного с указанием, фиксируются ли они по документам и каким именно, со слов нарушителя или очевидцев, которые его хорошо знают); время (час, минуты), основания и мотивы задержания; объяснения нарушителя и его состояние (состояние здоровья, наличие и характер травм, опьянение, состояние одежды и т.п.). В составлении протокола могут принимать участие лица, непосредственно доставившие нарушителя ${ }^{40}$.

Протокол об административном задержании регистрируется и докладывается вместе с протоколом об административном правонарушении, послужившем основанием задержания, должностному лицу, полномочному принять решение об административном задержании ${ }^{41}$.

\footnotetext{
${ }^{40}$ См.: Попугаев Ю.И. Указ. раб. - С. 8.

${ }^{41}$ Куракин А.В. Компетенция полиции в сфере реализации законодательства об административных правонарушениях // Административное и муниципальное право. 2013. - № 6. - C. 123.
} 


\section{Полицейская деятельность 2 • 2014}

Оважностипроцессуальныхдокументов в деле применения мер административного пресечения могут служить материалы судебной практики.

Так, 11 октября 2003 г. в 18 час. 30 мин. в г. Иваново гр. Г. был остановлен инспекторами ДПС Кирдиным и Чередниковым, которые потребовали у него предъявить удостоверение личности и документы на автомобиль. Он отказался, ссылаясь на то, что предъявит их только в Ленинском РОВД г. Иваново. После доставления в Ленинское РОВД гр. Г. предъявил оперативному дежурному и инспекторам ДПС требуемые документы. В этот же день оперативным дежурным Ленинского РОВД г. Иваново в отношении гр. Г. было составлено два протокола: об административном правонарушении, предусмотренном cm. 19.3 КоАП РФ, и об административном задержании в порядке cm. cm. 27.3-27.7 КоАП РФ, на основании которого его подвергли административному задержанию с 19 час. 45 мин. 11 октября 2003 г. до 9 час. 12 октября 2003 г.

Гр. Г., не согласившись с протоколом об административном задержании, обжаловал его в суд. Определением судьи Ленинского районного суда г. Иваново от 9 фревраля 2004 г., оставленным без изменения определением судьи Ивановского областного суда от 24 февраля 2004 г., жалоба оставлена без удовлетворения. В жалобе гр. Г. просил состоявшиеся по делу судебные постановления отменить как вынесенные с нарушением норм КоАП РФ.

Заместитель Председателя Верховного Суда Российской Федерации, рассмотрев 11 апреля 2005 г. жалобу гр. Г., счел ее подлежащей удовлетворению по следующим основаниям. Отказывая в удовлетворении жалобы, судья сослался на составленный в отношении гр. Г. 11 октября 2003 г. протокол об административном правонарушении, предусмотренном cm. 19.3 КоАП РФ, наказание за которое согласно санкции статьи - ад- министративный арест, и пришел к выводу о соответствии требованиям закона действий должностного лица РОВД по административному задержанию гр. Г.

Данный вывод сделан судом без установления и оценки всех обстоятельств, имеющих значение для правильного разрешения дела.

Административное задержание является принудительной мерой, ограничивающей свободу лица, и согласно сm. 27.3 КоАП РФ может быть применено в исключительных случаях: если это необходимо для обеспечения правильного и своевременного рассмотрения дела об административном правонарушении и в связи с исполнением постановления по делу об административном правонарушении.

Сам по себе факт составления в отношении лица протокола об административном правонарушении, за которое может быть назначено наказание в виде административного ареста, не может служить основанием для административного задержания лица.

Мотивы задержания должны быть указаны в протоколе об административном задержании (4. $1 \mathrm{~cm}$. 27.4 КоАП РФ).

В нарушение этого требования закона в протоколе об административном задержании гр. Г. такие мотивы не приведены.

Доводы оперативного дежурного РОВД в ходе судебного заседания о том, что задержание обусловлено необходимостью обеспечить присутствие гр. Г. при рассмотрении дела мировым судьей, нельзя признать обоснованными. Гр. Г. имеет постоянное место жительства в г. Иваново, семью. Данных о его намерении уклониться от явки в суд по делу не имеется.

Как следует из материалов дела, основанием для составления протокола об административном правонарушении по 4. $1 \mathrm{~cm}$. 19.3 КоАП РФ послужил отказ гр. Г. предъявить сотрудникам ГИБДД водительское удостоверение и документы на автомобиль, при управлении которым он 
был остановлен для проверки документов. При этом гр. Г. не возражал предъявить их в отделе внутренних дел, и по прибытии туда требуемые документы им были предъявлены оперативному дежурному отдела и инспекторам ДПС.

В обоснование отказа выполнить требование должностных лиц о предъявлении документов на месте остановки ими транспортного средства гр. Г. сослался на имевшие место ранее фракты незаконных действий сотрудников ГИБДД 2. Иваново по изъятию у него документов, установленные решением суда.

Эти доводы заявителя подлежали проверке и оценке. Однако судом не было предложено гр. Г. представить доказательства в подтверждение обстоятельств, на которые он ссылался, не были истребованы соответствующие документы и по инициативе суда.

Копиями решения Фрунзенского районного суда г. Иваново от 11 сентября 2000 г. и определения судьи Ивановского областного суда от 24 октября 2000 г. подтверждены доводы гр. Г. о незаконном изъятии у него документов сотрудниками ГИБДД г. Иваново 15 августа 2000 г.

При таких обстоятельствах отказ предъявить документы на право управления автомобилем и удостоверение личности непосредственно на улице не могут быть расценены как исключительные основания для составления протокола об административном задержании.

С учетом изложенного, составленный в отношении гр. Г. протокол об административном задержании признан незаконным, определение судьи Ленинского районного суда г. Иваново от 9 фревраля 2004 г. и определение судьи Ивановского областного суда от 24 февраля 2004 г. отменены, и производство по делу прекращено 42.

\footnotetext{
${ }^{42}$ См.: Бюллетень Верховного Суда Российской Федера-
} ции. -2005 . - № 11 .
Представляется целесообразным также кратко рссмотреть вопрос об отмене или изменении меры административного пресечения. Отмена и изменение мер административного пресечения должны происходить своевременно. Это означает, что необходимо безотлагательно отменять и изменять меры пресечения в нужный, обусловливаемый обстоятельствами дела момент. Подобная необходимость основана на требовании быстроты и оперативности административного процесса. Быстрота имеет отношение не только к раскрытию правонарушений и установлению истины, но и к обеспечению правильного применения закона. Поэтому выступает как коренное условие построения и проведения всей процессуальной деятельности по делам об административных правонарушениях. Суть ее - максимальное быстрое, в пределах возможного, осуществление административно-процессуальной деятельности при неуклонном соблюдении всех принципов и правил административного процесса ${ }^{43}$.

Требование своевременности отмены и изменения мер административного пресечения вытекает также из положений ряда нормативных правовых актов. Как требование, базирующееся на правовых нормах и подлежащее исполнению, своевременность является составным элементом принципа верховенства закона ${ }^{44}$.

В сущностном плане принципиальное значение ее в том, что она служит гарантией реальной охраны законных интересов как государства, так и личности. В частности, своевременное использование мер пресечения является гарантом жизнеобеспечения таких ценностей, как предупреждение уклонения обвиняемого от следствия и правосудия, предотвращение новых преступлений с его стороны и ли-

\footnotetext{
${ }^{43}$ Куракин А.В. Компетенция полиции в сфере реализации законодательства об административных правонарушениях // Административное и муниципальное право. 2013. - № 6. - C. 123.

${ }^{44}$ См.: Мосин М.В. Указ. раб. - С. 15.
} 


\section{Полицейская деятельность 2 • 2014}

шение возможности противодействия им установлению истины по уголовному делу. Как показывает практика, когда диктуемые обстоятельствами дела законные средства пресечения приводятся в действие именно в нужный (определяемый наличием оснований) момент, всегда достигаются желаемые результаты, в том числе в экономическом плане сбережение времени, сил и ресурсов. В тех же случаях, когда упускается время, требование своевре- менности не соблюдается, наоборот, трудно достичь таких результатов. Об этом свидетельствуют многочисленные фракты негативного характера по причине того, что требуемые меры пресечения вовремя не применяются. Промедление с применением меры пресечения отрицательно влияет на ход и исход самого дела об административном правонарушении, крайне затрудняет, а подчас делает невозможным воздать должное правонарушителю.

\section{Библиография:}

1. Абулгазин С.Б. Административно-правовые отношения в деятельности милиции по охране общественного порядка: дис. ... канд. юрид. наук. - М., 1982.

2. Алехин А.П., Козлов Ю.М. Административное право Российской Федерации. - М., 1995.

3. Зеленко В.Л. Вопросы теории и практики применения милицией мер административного пресечения правонарушений: авторефр. дис. ... канд. юрид. наук. - Киев, 1975.

4. Котюргин С.И. Функции советской милиции. - Омск, 1975.

5. Козлов Ю.М. Административные правоотношения. - М., 1976.

6. Кисин В.Р. Меры административно-процессуального принуждения...... дис. ... канд. юрид. наук. - М., 1983.

7. Коренев А.П. Административная деятельность органов внутренних дел. Часть особенная / А.П. Коренев [и др.]. - М.: Щит-М, 2003.

8. Капитонов С.А. Ведущая функция милиции / С.А. Капитонов. - М.: Юриспруденция, 2002.

9. Каплунов А.И. Применение и использование огнестрельного оружия / А.И. Каплунов, С.Ф. Милюков. - СПб.: Юридический центр Пресс, 2003.

10. Костенников М.В. Административная деятельность органов внутренних дел. Особенная часть. / М.В. Костенников, А.В. Куракин. - М.: Щит-М, 2003.

11. Костенников М.В. Актуальные проблемы административно-правового регулирования / М.В. Костенников, А.В. Куракин. Т. 1. - М.: Маросейка, 2010.

12. Костенников М.В. Административный запрет как средство противодействия коррупции в системе государственной службы / М.В. Костенников, А.В. Куракин. - М.: ЮНИТИ-ДАНА, Закон и право, 2010.

13. Куракин А.В. Актуальные проблемы науки административного права. - М.: Маросейка, 2011.

14. Костенников М.В. Административный финансовый контроль в системе МВД России / М.В. Костенников, А.В. Куракин, В.Н. Кузнецов. - Домодедово: ВИПК МВД России, 2011.

15. Куракин А.В. Предмет административно-правового регулирования в механизме противодействия коррупции в полиции. - Домодедово, 2013.

16. Лапшин В.Н. Административные правоотношения в деятельности органов внутренних дел. - Караганда, 1986.

17. Петров Г.И. Советские административно-правовые отношения. - Л., 1972.

18. Пастушенко Е.Н. Функции административного принуждения по советскому законодательству: автореф. дис. ... канд. юрид. наук. - Саратов, 1986. 
19. Попугаев Ю.И. Административно-процессуальные меры, применяемые в связи с совершением правонарушения: автореф. дис. ... канд. юрид. наук. - М., 1991.

20. Тюрин В.А. Проблемы применения мер пресечения в административном праве: дис. ... д-ра юрид. наук. - М., 2004.

21. Трегубова Е.В. Административные запреты в сфере осуществления полицейской деятельности // NB: Российское полицейское право. - 2013. - 1. - C. 25-44. DOI: 10.7256/23064218.2013.1.718. URL: http://www.e-notabene.ru/pm/article_718.html

22. Куракин А.В., Костенников М.В. Административно-правовое противодействие коррупции в системе государственной службы и в деятельности сотрудников полиции Российской Федерации и зарубежных государств // NB: Российское полицейское право. - 2013. - 1. - С. 65-83. DOI: 10.7256/2306-4218.2013.1.735. URL: http://www.e-notabene.ru/pm/article_735.html

23. Куракин А.В., Костенников М.В. Принципы организации и деятельности российской полиции // NB: Российское полицейское право. - 2013. - 2. - C. 22-49. DOI: 10.7256/23064218.2013.2.799. URL: http://www.e-notabene.ru/pm/article_799.html

24. Куракин А.В. Компетенция полиции в сфере реализации законодательства об административных правонарушениях // NB: Административное право и практика администрирования. - 2013. - 4. - C. 28-48. DOI: 10.7256/2306-9945.2013.4.8841. URL: http://www.e-notabene.ru/ al/article_8841.html

25. Куракин А.В. Социальная политика и российская полиция // NB: Российское полицейское право.-2013.-3.-C. 1-23. DOI: 10.7256/2306-4218.2013.3.8914. URL: http://www.e-notabene. ru/pm/article_8914.html

26. Соломатина Е.А. Правовое регулирование деятельности полиции в зарубежных странах // NB: Российское полицейское право. - 2013. - 3. - C. 104-118. DOI: 10.7256/23064218.2013.3.8916. URL: http://www.e-notabene.ru/pm/article_8916.html

27. Айрих В.А. Соотношение общественной безопасности и превенции в полицейском праве ФРГ // NB: Национальная безопасность. - 2013. - 1. - C. 254-289. DOI: 10.7256/23060417.2013.1.312. URL: http://www.e-notabene.ru/nb/article_312.html

28. Насанжаргалын Ганбадрал Проблемы применения мер административного принуждения полицией Монголии // Полицейская деятельность. - 2011. - 4. - С. 68-71.

29. Кареева-Попелковская К.А. Институт административного принуждения в системе государственного принуждения и его реализация в деятельности органов внутренних дел // Полицейская деятельность. - 2011. - 6. - С. 46-55.

30. Несмелов П.В. Правовое регулирование применения сотрудниками полиции фризической силы, специальных средств и огнестрельного оружия // Полицейская деятельность. 2013. - 2. - C. 100-103. DOI: 10.7256/2222-1964.2013.02.4.

31. Астишина Т.В., Маркелова Е.В., Обгольц И.А.. Предупреждение полицией преступлений несовершеннолетних. // Полицейская деятельность. - 2013. - № 2. - C. 93-99. DOI: $.10 .7256 / 2222-1964.2013 .02$.

\section{References (transliteration):}

1. Abulgazin S.B. Administrativno-pravovye otnosheniya $v$ deyatel'nosti militsii po okhrane obshchestvennogo poryadka: dis. ... kand. yurid. nauk. - M., 1982.

2. Alekhin A.P., Kozlov Yu.M. Administrativnoe pravo Rossiiskoi Federatsii. - M., 1995.

3. Zelenko V.L. Voprosy teorii i praktiki primeneniya militsiei mer administrativnogo presecheniya pravonarushenii: avtoref. dis. ... kand. yurid. nauk. - Kiev, 1975. 


\section{Полицейская деятельность 2 • 2014}

4. Kotyurgin S.I. Funktsii sovetskoi militsii. - Omsk, 1975.

5. Kozlov Yu.M. Administrativnye pravootnosheniya. - M., 1976.

6. Kisin V.R. Mery administrativno-protsessual'nogo prinuzhdeniya...... dis. ... kand. yurid. nauk. M., 1983.

7. Korenev A.P. Administrativnaya deyatel'nost' organov vnutrennikh del. Chast' osobennaya / A.P. Korenev [i dr.]. - M.: Shchit-M, 2003.

8. Kapitonov S.A. Vedushchaya funktsiya militsii / S.A. Kapitonov. - M.: Yurisprudentsiya, 2002.

9. Kaplunov A.I. Primenenie i ispol'zovanie ognestrel'nogo oruzhiya / A.I. Kaplunov, S.F. Milyukov. - SPb.: Yuridicheskii tsentr Press, 2003.

10. Kostennikov M.V. Administrativnaya deyatel'nost' organov vnutrennikh del. Osobennaya chast'. / M.V. Kostennikov, A.V. Kurakin. - M.: Shchit-M, 2003.

11. Kostennikov M.V. Aktual'nye problemy administrativno-pravovogo regulirovaniya / M.V. Kostennikov, A.V. Kurakin. T. 1. - M.: Maroseika, 2010.

12. Kostennikov M.V. Administrativnyi zapret kak sredstvo protivodeistviya korruptsii v sisteme gosudarstvennoi sluzhby / M.V. Kostennikov, A.V. Kurakin. - M.: YuNITI-DANA, Zakon i pravo, 2010.

13. Kurakin A.V. Aktual'nye problemy nauki administrativnogo prava. - M.: Maroseika, 2011.

14. Kostennikov M.V. Administrativnyi finansovyi kontrol' v sisteme MVD Rossii / M.V. Kostennikov, A.V. Kurakin, V.N. Kuznetsov. - Domodedovo: VIPK MVD Rossii, 2011.

15. Kurakin A.V. Predmet administrativno-pravovogo regulirovaniya $v$ mekhanizme protivodeistviya korruptsii v politsii. - Domodedovo, 2013.

16. Lapshin V.N. Administrativnye pravootnosheniya $v$ deyatel'nosti organov vnutrennikh del. Karaganda, 1986.

17. Petrov G.I. Sovetskie administrativno-pravovye otnosheniya. - L., 1972.

18. Pastushenko E.N. Funktsii administrativnogo prinuzhdeniya po sovetskomu zakonodatel'stvu: avtoref. dis. ... kand. yurid. nauk. - Saratov, 1986.

19. Popugaev Yu.I. Administrativno-protsessual'nye mery, primenyaemye v svyazi s soversheniem pravonarusheniya: avtoref. dis. ... kand. yurid. nauk. - M., 1991.

20. Tyurin V.A. Problemy primeneniya mer presecheniya $v$ administrativnom prave: dis. ... d-ra yurid. nauk. - M., 2004.

21. Tregubova E.V. Administrativnye zaprety v sfere osushchestvleniya politseiskoi deyatel'nosti // NB: Rossiiskoe politseiskoe pravo. - 2013. - 1. - C. 25-44. DOI: 10.7256/2306-4218.2013.1.718. URL: http://www.e-notabene.ru/pm/article_718.html

22. Kurakin A.V., Kostennikov M.V. Administrativno-pravovoe protivodeistvie korruptsii v sisteme gosudarstvennoi sluzhby i v deyatel'nosti sotrudnikov politsii Rossiiskoi Federatsii i zarubezhnykh gosudarstv // NB: Rossiiskoe politseiskoe pravo. - 2013. - 1. - C. 65-83. DOI: 10.7256/23064218.2013.1.735. URL: http://www.e-notabene.ru/pm/article_735.html

23. Kurakin A.V., Kostennikov M.V. Printsipy organizatsii i deyatel'nosti rossiiskoi politsii // NB: Rossiiskoe politseiskoe pravo. - 2013. - 2 . - C. 22-49. DOI: 10.7256/2306-4218.2013.2.799. URL: http://www.e-notabene.ru/pm/article_799.html

24. Kurakin A.V. Kompetentsiya politsii $v$ sfere realizatsii zakonodatel'stva ob administrativnykh pravonarusheniyakh // NB: Administrativnoe pravo i praktika administrirovaniya. - 2013. - 4. - C. 2848. DOI: 10.7256/2306-9945.2013.4.8841. URL: http://www.e-notabene.ru/al/article_8841.html

25. Kurakin A.V. Sotsial'naya politika i rossiiskaya politsiya // NB: Rossiiskoe politseiskoe pravo. - 2013. - 3. - C. 1-23. DOI: 10.7256/2306-4218.2013.3.8914. URL: http://www.e-notabene.ru/pm/article_8914.html

26. Solomatina E.A. Pravovoe regulirovanie deyatel'nosti politsii v zarubezhnykh stranakh // NB: Rossiiskoe politseiskoe pravo. - 2013. - 3. - C. 104-118. DOI: 10.7256/2306-4218.2013.3.8916. URL: http://www.e-notabene.ru/pm/article_8916.html 
27. Airikh V.A. Sootnoshenie obshchestvennoi bezopasnosti i preventsii $v$ politseiskom prave FRG // NB: Natsional'naya bezopasnost'. - 2013. - 1. - C. 254-289. DOI: 10.7256/23060417.2013.1.312. URL: http://www.e-notabene.ru/nb/article_312.html

28. Nasanzhargalyn Ganbadral Problemy primeneniya mer administrativnogo prinuzhdeniya politsiei Mongolii // Politseiskaya deyatel'nost'. - 2011. - 4. - C. 68-71.

29. Kareeva-Popelkovskaya K.A. Institut administrativnogo prinuzhdeniya $v$ sisteme gosudarstvennogo prinuzhdeniya i ego realizatsiya $v$ deyatel'nosti organov vnutrennikh del // Politseiskaya deyatel'nost'. - 2011. - 6. - C. 46-55.

30. Nesmelov P.V. Pravovoe regulirovanie primeneniya sotrudnikami politsii fizicheskoi sily, spetsial'nykh sredstv i ognestrel'nogo oruzhiya // Politseiskaya deyatel'nost'. - 2013. - 2. C. 100-103. DOI: 10.7256/2222-1964.2013.02.4.

31. Astishina T.V., Markelova E.V., Obgol'ts I.A.. Preduprezhdenie politsiei prestuplenii nesovershennoletnikh. // Politseiskaya deyatel'nost'. - 2013. - № 2. - C. 93-99. DOI: .10.7256/22221964.2013.02. 